\title{
In vitro flowering and production of viable pollen of cucumber
}

\author{
Agnieszka Kiełkowska • Michael J. Havey
}

Received: 6 July 2011/ Accepted: 22 October 2011/Published online: 16 November 2011

(C) The Author(s) 2011. This article is published with open access at Springerlink.com

\begin{abstract}
Flowers were produced on sterile cucumber (Cucumis sativus L.) plants grown in vitro from seed and micropropagated shoots from stem fragments. The highest numbers of flowers on plants from both sources were produced on Murashige and Skoog (MS) medium without plant growth regulators (PGR), as well as with $6 \mu \mathrm{M}$ of kinetin (Kin). Plants cultured on MS medium supplemented with $8.9 \mu \mathrm{M}$ benzyladenine (BA) and $1.1 \mu \mathrm{M}$ 1-naphthaleneacetic acid (NAA) did not flower. In vitro grown plants produced fewer, smaller flowers compared with greenhouse-grown plants. Male and female flowers developed on plants grown in vitro from seed and were morphologically similar to flowers on greenhouse grown plants. Micropropagated shoots produced male flowers with altered morphology. The highest viability $(72.9 \pm 4.2 \%)$ and germination $(69.5 \pm 4.1 \%)$ of pollen were observed for plants grown from seed on MS medium supplemented with $6 \mu \mathrm{M}$ Kin. Cytological observations of meiosis in anthers of male flowers from in vitro grown plants revealed abnormalities, such as monads, dyads, triads, polyads, microcytes and degeneration of tetrads, causing reduced viability and germination of pollen. The fewest meiotic irregularities in pollen mother cells were observed in plants grown on MS medium that was PGRfree $(12.1 \pm 0.9 \%)$ or with $6 \mu \mathrm{M}$ Kin $(20.9 \pm 1.7 \%)$.
\end{abstract}

Keywords In vitro flowering - Meiotic irregularities . Pollen viability and germination $\cdot$ Tetrads

A. Kiełkowska $(\bowtie) \cdot$ M. J. Havey

USDA-ARS and Department of Horticulture,

University of Wisconsin, Madison, WI 53706, USA

e-mail: kielkowska@ogr.ur.krakow.pl

\author{
Abbreviations \\ BA 6-Benzyladenine \\ 2,4-D 2,4-Dichlorophenoxyacetic acid \\ $\mathrm{GA}_{4+7}$ Mixture of gibberelic acid A4 and A7 \\ EDTA Ethylene diamine tetra acetic acid \\ IAA Indole-3-acetic acid \\ Kin Kinetin \\ NAA 1-naphthaleneacetic acid \\ MS Murashige and Skoog (1962) \\ PGR Plant growth regulator \\ PMC Pollen mother cell
}

\section{Introduction}

Flower formation on in vitro grown plants has been reported for many species using different explant sources to investigate the influence of medium, plant growth regulators and photoperiod on flowering (Bhat et al. 2010; Jana and Shekhawat 2011; Masmoudi-Allouche et al. 2010). In vitro production of flowers is especially important for ornamental plants such as orchids (Hee et al. 2007), roses (Kanchanapoom et al. 2010b), jasminum (Jumin and Ahmad 1999), bamboo (John and Nadgauda 1999; Lin et al. 2003; Ramanayake et al. 2001), among others (Bodhipadma et al. 2011; Hu et al. 2010; Kanchanapoom et al. 2010a; Taha et al. 2010). In these species, early in vitro flowering of micropropagated plantlets shortens the breeding cycle to meet market demands.

In vitro flowering in vegetables is important for selective hybridization with pollen from rare accessions, enabling synchronization of flowering, and studying the physiology of flowering (Franklin et al. 2000; Sheeja and Mandal 2003). In vitro flowering has been reported for pepper (Tisserat and Galletta 1995), tomato (Sheeja and Mandal 
2003), spinach (Al-Khayri et al. 1992), pea (Franklin et al. 2000), cauliflower (Kumar et al. 1995) and cucumber (Rajasekaran et al. 1983; Msikita et al. 1990; Tisserat and Galltetta 1993). Rajasekaran et al. (1983) cultured hypocotyl segments of cucumber in liquid Murashige and Skoog (MS) (1962) medium supplemented with BA (6-benzyladenine) and 2,4-dichlorophenoxyacetic acid (2,4-D). Callus tissue was observed on explants and, when transferred to medium without plant growth regulators (PGRs), somatic embryos and adventitious buds were formed. Regenerated plants produced relatively rare, but normalappearing male flowers, on several plantlets malformed female-like flowers were noted. Msikita et al. (1990) used pieces of seed comprising an embryonic axis and cotyledons, cultured on MS based solid medium supplemented with BA in combination with NAA (1-naphthaleneacetic acid). Plantlets regenerated from the axes did not flower, and only some of cotyledon-derived plantlets developed male flowers. Production of the single parthenocarpic cucumber fruits by use of an automated culture system administering compressed air has also been reported (Tisserat and Galltetta 1993). These reports demonstrate that flowering of cucumber in tissue culture depends on explant type, media composition, PGRs types and their concentrations; however information about pollen quality is very limited. Detailed cytological study of pollen from in vitro produced flowers has not been reported for cucumber. The goal of this study was to identify the most efficient factors (explant, medium) to induce flowering on in vitro grown plants of cucumber and to assess pollen quality towards the production of microspore cultures.

\section{Materials and methods}

Plant material and tissue culture

Cucumber seeds were obtained of inbred line B (Burza and Malepszy 1995), a Chinese hybrid (CH) 'Ningjia No. 1' previously reported to produce haploid plants from anther culture (Song et al. 2007), and a recessive glabrous (G) mutant (Inggamer and de Ponti 1980, kindly provided by Dr. Todd Wehner, North Carolina State University). Seeds were soaked in tap water for 1-2 h, surface-disinfected in $70 \%(\mathrm{v} / \mathrm{v})$ ethanol for $5 \mathrm{~min}, 10 \%(\mathrm{w} / \mathrm{v})$ of solution of Chloramine T (Sigma, St Louis, MO) in water for $15 \mathrm{~min}$, and rinsed three times in sterile water for $5 \mathrm{~min}$ each. Seeds were then placed in 300-ml Magenta boxes (Magenta Corp., Chicago, IL) containing $60 \mathrm{ml}$ of basal MS medium. Basal MS medium was prepared using powdered MS salt mixture including vitamins (Phyto Technology Laboratories, Shawnee Mission, KS, USA).
Various combinations of basal MS media with and without PGRs were used: MSB (MS medium $+2 \mu \mathrm{M}$ BA), MSP (MS medium + 8.9 $\mu \mathrm{M}$ BA), MSC (MS medium $+8.9 \mu \mathrm{M} \mathrm{BA}+1.1 \mu \mathrm{M}$ NAA), MSK (MS medium $+6 \mu \mathrm{M}$ Kin), and PGRs free MS. All media were supplemented with $90 \mathrm{mM}$ sucrose, adjusted to $\mathrm{pH}$ of 5.7-5.8 and $0.25 \%$ (w/v) Phytagel was added (Sigma, St. Louis, MO) prior to autoclaving $\left(20 \mathrm{~min}\right.$ at $121^{\circ} \mathrm{C}$; $1.4 \times 10^{4} \mathrm{~kg} \mathrm{~m}^{-2}$ ). These media were tested for their ability to induce flowers on intact plants (IP) grown from seed, and on plants micro-propagated (MP) from stem fragments.

To assess flowering on IPs, 2-week-old seedlings that were sterile, vigorous, and possessed two well developed cotyledons were transferred to induction media MSB, MSP, MSC, MSK and MS in 2-1 wide-mouth Mason (Jarden Corp., Rye, NY) jars. To facilitate air exchange, jars were covered with Sun bag (Sigma, St Louis, MO) autoclavable transparent sheets with a polypropylene $0.02 \mu \mathrm{m}$ filter in the center, held in place by a threaded metal ring.

For MPs, 3-week-old seedlings possessing one or two well developed true leaves were used. Two-centimeter stem pieces with 2 axillary buds were cut from seedlings and placed into Magenta boxes with $60 \mathrm{ml}$ of MSB, MSP, MSC or MS. Boxes were closed with a polypropylene closure equipped with $0.02 \mu \mathrm{m}, 10 \mathrm{~mm}$ diameter vent. Observations of shoot tips with visible leaf primordia were performed after 4 weeks of culture. Jars and boxes were placed under a $16 \mathrm{~h}$ photoperiod with light supplied by Philips cool-white fluorescent lamps $\left(80 \mu \mathrm{mol} \mathrm{m} \mathrm{m}^{-2} \mathrm{~s}^{-1}\right)$ at $28 \pm 2{ }^{\circ} \mathrm{C}$. Plants were transferred to fresh media every 4 weeks until flowering.

Biometric analyses

For both IP and MP cultured plants, data were collected on the number of male flowers, including flower buds and open flowers; the number of days to formation of first open male flower (counted from the date of first transfer to the induction medium); the length $(\mathrm{cm})$, diameter $(\mathrm{cm})$, number and length $(\mathrm{cm})$ of the petals and number of anthers in the open flowers; number and position on the plant of female flowers; plant height $(\mathrm{cm})$ and number of nodes on the main stem. For measurements of male and female flowers, greenhouse-grown plants were used as controls.

Observations of pollen viability and pollen germination

Pollen was stained with Alexander (1969) dye and observed under a white fluorescent light microscope (Carl Zeiss, Göttingen, Germany). Acid fuchsin, present in this dye, stains the protoplasm and malachite green stains 
cellulose in walls of pollen; dark purple pollen was scored as viable and green as aborted. Germination of pollen from open male flowers was counted after incubation for $24 \mathrm{~h}$ at $25^{\circ} \mathrm{C}$ on germination medium (GM) consisting of $15 \%(\mathrm{w} / \mathrm{v})$ maltose, $0.16 \mathrm{mM}$ boric acid, $1 \mathrm{mM}$ calcium nitrate at $\mathrm{pH}$ 7.0 (Vižintin and Bohanec 2004), and 0.25\% (w/v) Phytagel. Observations were made on a minimum of 3000 pollen from each culture medium. As a control, pollen from greenhouse-grown plants was used.

\section{Cytological observation of tetrads}

Flower buds of $1-4 \mathrm{~mm}$ in length were fixed in a mixture of ethanol, chloroform and acetic acid $(6: 3: 1 \mathrm{v} / \mathrm{v})$ for 24-48 h, washed with $70 \%$ ethanol and refrigerated until use. Tetrads were stained after squashing extracted anthers in $1 \%$ acetocarmine. Over 3000 cells were analyzed for each treatment and were photographed with a monochromic AxioCam MRc (Carl Zeiss, Göttingen, Germany) camera.

\section{Statistical analysis}

For IP, each treatment consisted of five jars with one plant per jar for each of the three cucumber accessions on each of the five induction media. For MP, each treatment consisted of 3 Magenta boxes with three explants per box for the three cucumber accessions on each of four media. Both experiments were repeated twice. Data for biometric analyses from in vitro cultured plants were collected from minimum 5 plants from each accession on each medium with two replications. For the greenhouse-grown (control) plants, data were collected from eight randomly chosen plants for each accession. Data were analyzed using a factorial-design ANOVA and mean separations were conducted via Duncan's multiple range tests (DMRT) test at $P \leq 0.05$.

\section{Results}

Induction of multiple shoots in vitro

Cucumber shoots developed from axillary buds during the first two weeks of culture, and adventitious shoots appeared about the third week. The highest mean number (3.4 \pm 0.2$)$ of shoots per explant was obtained on the PGRfree medium (Table 1) and the majority of shoots developed on this medium were rooted by the fourth to fifth week of culture. A lower amount of BA $(2 \mu \mathrm{M})$ was more favorable $(2.6 \pm 0.3$ /explant $)$ on shoot development than a higher level $(8 \mu \mathrm{M}$ in MSP medium). The MSC medium supplemented with auxin and cytokinin formed
Table 1 Mean number of shoots per explant ( \pm standard error) from cucumber stem fragments on induction media after 4 weeks of culture

\begin{tabular}{llll}
\hline Medium & \multicolumn{3}{l}{ Accession } \\
\cline { 2 - 4 } & $\mathrm{B}$ & $\mathrm{CH}$ & $\mathrm{G}$ \\
\hline MS & $4.1 \pm 0.2 \mathrm{a}$ & $3.6 \pm 0.2 \mathrm{a}$ & $2.6 \pm 0.2 \mathrm{a}$ \\
MSB & $2.2 \pm 0.2 \mathrm{~b}$ & $2.8 \pm 0.4 \mathrm{ab}$ & $2.7 \pm 0.2 \mathrm{a}$ \\
MSC & $1.6 \pm 0.2 \mathrm{~b}$ & $0.8 \pm 0.1 \mathrm{c}$ & $0.8 \pm 0.1 \mathrm{~b}$ \\
MSP & $2.3 \pm 0.2 \mathrm{~b}$ & $2.1 \pm 0.2 \mathrm{~b}$ & $1.5 \pm 0.2 \mathrm{~b}$ \\
\hline
\end{tabular}

$\mathrm{B}$, inbred B; $\mathrm{CH}$, Chinese Hybrid; $\mathrm{G}$, glabrous mutant. Means in column followed by the same letter are not significantly different $(P \leq 0.05$, DMRT $)$

white-greenish callus on explants, together with shoot development. This callus formation was so intensive that all subsequent shoots were yellowish-brown and eventually died, in spite of subculturing, and this medium was not investigated further.

Induction of in vitro flowering and biometric analysis of flowering plants

After 4 weeks of culture IP plantlets developed a main stem with nodes and possessed several true leaves; all plants were well rooted. The MP plantlets at the same period were shorter, with one or two true leaves (Fig. 1a). The physiological differences between plantlets originating from different sources influenced the time of flowering. After 60 days of culture, $80-90 \%$ of IP and only $12-20 \%$ of MP plants had flowered in vitro (Fig. 2). For IPs, $84 \%$ flowered on PGR-free MS medium, which increased to $98 \%$ with the addition of $6 \mu \mathrm{M}$ Kin. MP plants started to flower on average between the 65th and 93rd day after first passage to induction media (Table 2, Fig. 1b, c); IPs flowered earlier, on average between the 28th and 62nd day. Flowering was induced for all three cucumber accessions on each of the tested media except MS supplemented with combination of BA and NAA (MSC). The earliest flowering was after 28 days for IP plants cultured on the media supplemented with $6 \mu \mathrm{M}$ Kin (MSK), flowering twice as fast as any other medium.

We observed significant effects of accession and induction medium on flower production by IP and MP plants of cucumber (Table 3). The highest number (mean $106 \pm 24.4$ /plant) of male flowers was produced by inbred line $\mathrm{B}$, and the highest number of female flowers was observed on the glabrous mutant. The highest mean number of flowers in both experiments was produced on the PGR-free medium. Male flowers were produced on whole plants at similar frequencies for media supplemented with $2 \mu \mathrm{M}$ of BA (MSB) or $6 \mu \mathrm{M}$ of Kin (MSK).

Media significantly affected plant height and number of stem nodes (Table 4). The tallest $(24.2 \pm 2.0 \mathrm{~cm})$ plants 

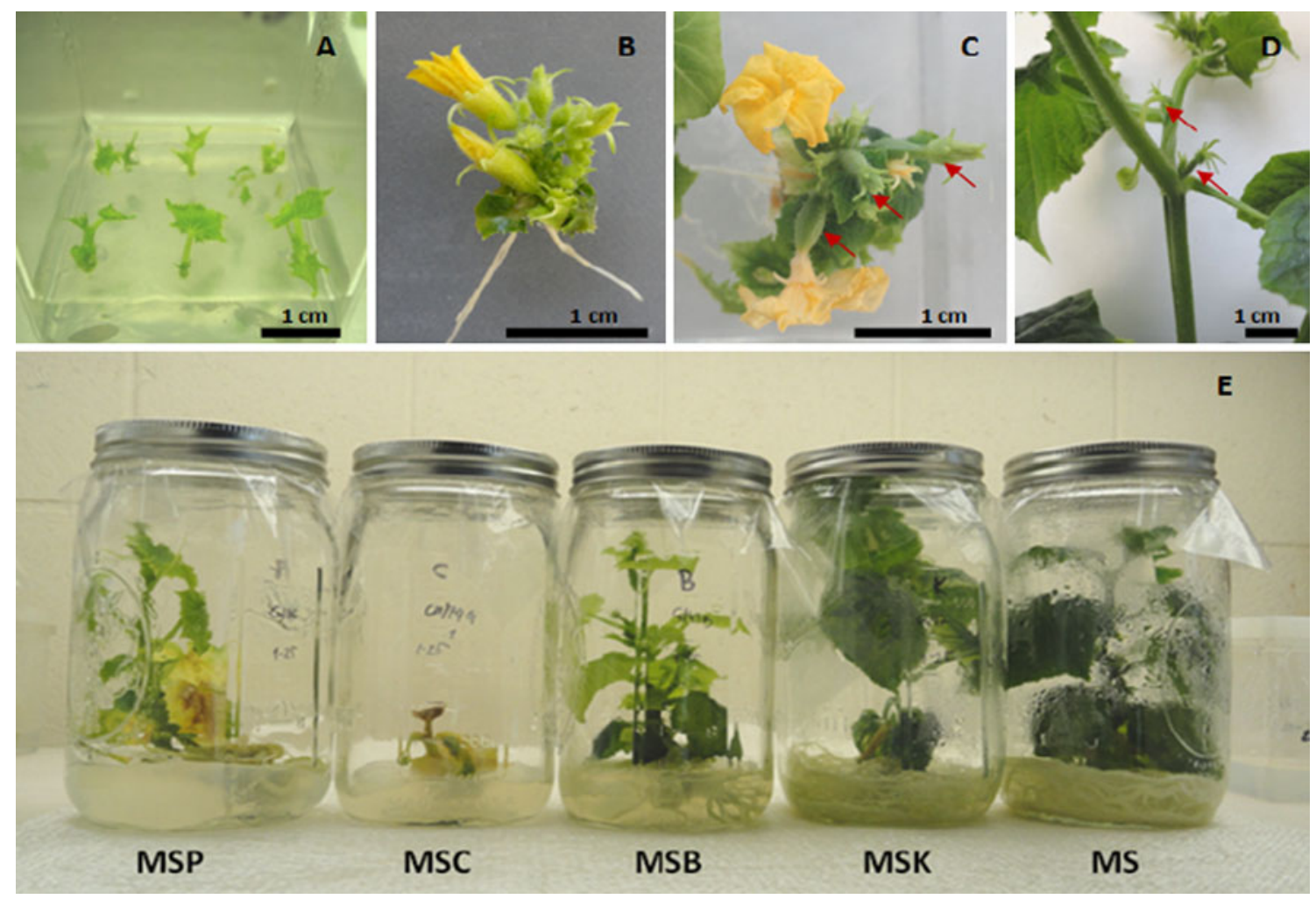

Fig. 1 In vitro propagation and flowering of cucumber (Cucumis sativus L.). Micropropagated plantlets (MP) cultured on MS PGR-free medium (a), and with developed male flowers (b). Female flowers

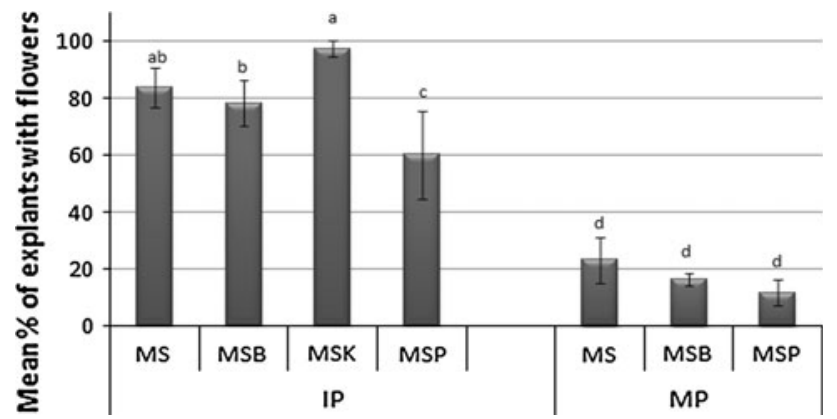

Fig. 2 Mean percent ( \pm standard error) of intact (IP) and micropropagated (MP) cucumber plants with flowers after 60 days of culture MS, MSB, MSK, MSP = induction media

were observed on PGR-free MS medium and MS medium with Kin $(19.5 \pm 1.7 \mathrm{~cm})$. MP plants cultured on the media with BA (MSB and MSP) were much shorter $(2.4 \pm 0.4-7.4 \pm 1.5 \mathrm{~cm})$ and became chlorotic on the upper part of the stem after 4 weeks of culture.

There were no significant differences in plant height and number of main stem nodes between cucumber accessions (Table 4). In general IPs were taller with 8-10 nodes, as compared to MP plants which produced on average 5-6 nodes. The appearance of IP plants cultured on the various indicated by arrows on micropropagated (c) and intact plant (d). Intact plants (IP) on various induction media (e)

Table 2 Mean number of days ( \pm standard error) from first passage to induction media until appearance of first open flower from intact and micropropagated cucumber plants

\begin{tabular}{lccl}
\hline Medium & \multicolumn{3}{l}{ Accession } \\
\cline { 2 - 4 } & $\mathrm{B}$ & $\mathrm{CH}$ & $\mathrm{G}$ \\
\hline Intact plants & & \\
MS & $68.6 \pm 7.3 \mathrm{bc}$ & $60.4 \pm 1.1 \mathrm{bc}$ & $35.6 \pm 4.2 \mathrm{~b}$ \\
MSB & $84.4 \pm 8.5 \mathrm{ab}$ & $52.6 \pm 3.7 \mathrm{bc}$ & $46.9 \pm 8.2 \mathrm{~b}$ \\
MSK & $26.9 \pm 3.1 \mathrm{~d}$ & $27.7 \pm 4.3 \mathrm{c}$ & $29.7 \pm 2.9 \mathrm{~b}$ \\
MSP & $103.0 \pm 0.0 \mathrm{a}$ & $42.0 \pm 12.1 \mathrm{c}$ & $42.1 \pm 10.8 \mathrm{~b}$ \\
Micro-propagated plants & & \\
MS & $36.9 \pm 4.9 \mathrm{~cd}$ & $54.0 \pm 2.8 \mathrm{bc}$ & $89.3 \pm 5.8 \mathrm{a}$ \\
MSB & $77.7 \pm 6.0 \mathrm{abc}$ & $115.4 \pm 18.0 \mathrm{a}$ & $88.3 \pm 1.7 \mathrm{a}$ \\
MSP & $80.6 \pm 7.4 \mathrm{ab}$ & $80.2 \pm 6.4 \mathrm{~b}$ & $99.0 \pm 8.9 \mathrm{a}$ \\
\hline
\end{tabular}

$\mathrm{B}$, inbred B; $\mathrm{CH}$, Chinese Hybrid; G, glabrous mutant. Values in column followed by the same letter are not significantly different $(P \leq 0.05, \mathrm{DMRT})$ and should be considered together for IP and MP

induction media is presented in Fig. 1e. We observed differences in the number of nodes depending on the medium. Whole plants cultured on the PGR-free medium possessed on average of $15 \pm 0.8$ nodes, micropropagated plants cultured on this same medium produced approximately half. We also noted the position of female flowers on 
Table 3 Average effect of the induction media on flower production ( \pm standard error) from intact and micropropagated cucumber plants

\begin{tabular}{|c|c|c|c|}
\hline \multirow[b]{2}{*}{ Medium } & \multicolumn{3}{|l|}{ Accession } \\
\hline & B & $\mathrm{CH}$ & G \\
\hline \multicolumn{4}{|c|}{ No. of male flowers per plant } \\
\hline \multicolumn{4}{|c|}{ Intact plants } \\
\hline MS & $161.5 \pm 23.9 \mathrm{a}$ & $51.3 \pm 4.9 b$ & $43.9 \pm 8.7 \mathrm{a}$ \\
\hline MSB & $120.5 \pm 47.8 \mathrm{a}$ & $121.8 \pm 2.9 \mathrm{a}$ & $27.0 \pm 4.8 \mathrm{a}$ \\
\hline MSK & $129.7 \pm 18.3 \mathrm{a}$ & $33.8 \pm 3.4 \mathrm{~b}$ & $42.3 \pm 10.4 a$ \\
\hline MSP & $11.4 \pm 7.7 \mathrm{~b}$ & $32.5 \pm 8.3 b$ & $18.7 \pm 7.4 \mathrm{a}$ \\
\hline \multicolumn{4}{|c|}{ Micro-propagated plants } \\
\hline MS & $131.0 \pm 1.5 \mathrm{a}$ & $18.4 \pm 3.9 \mathrm{~b}$ & $48.8 \pm 4.7 \mathrm{a}$ \\
\hline MSB & $13.7 \pm 4.5 b$ & $13.1 \pm 2.1 \mathrm{~b}$ & $29.8 \pm 6.4 \mathrm{a}$ \\
\hline MSP & $3.3 \pm 1.2 \mathrm{~b}$ & $3.3 \pm 0.7 b$ & $5.5 \pm 1.3 \mathrm{a}$ \\
\hline \multicolumn{4}{|c|}{ No. of female flowers per plant } \\
\hline \multicolumn{4}{|c|}{ Intact plants } \\
\hline MS & $0.9 \pm 0.2 \mathrm{a}$ & $0.8 \pm 0.6 \mathrm{a}$ & $3.3 \pm 1.3 \mathrm{a}$ \\
\hline MSB & $1.3 \pm 0.9 \mathrm{a}$ & $0.1 \pm 0.1 \mathrm{a}$ & $0.0 \mathrm{~b}$ \\
\hline MSK & $0.0 \pm 0.0 \mathrm{a}$ & $0.1 \pm 0.1 \mathrm{a}$ & $2.3 \pm 0.7 \mathrm{ab}$ \\
\hline MSP & $0.0 \pm 0.0 \mathrm{a}$ & $0.2 \pm 0.2 \mathrm{a}$ & $0.9 \pm 0.5 b$ \\
\hline \multicolumn{4}{|c|}{ Micro-propagated plants } \\
\hline MS & $0.1 \pm 0.1 \mathrm{a}$ & $0.1 \pm 0.1 \mathrm{a}$ & $2.1 \pm 0.9 \mathrm{ab}$ \\
\hline MSB & $0.8 \pm 0.3 \mathrm{a}$ & $0.1 \pm 0.1 \mathrm{a}$ & $0.2 \pm 0.1 b$ \\
\hline MSP & $0.1 \pm 0.1 \mathrm{a}$ & $0.0 \mathrm{a}$ & $0.0 \mathrm{~b}$ \\
\hline
\end{tabular}

B, inbred B; $\mathrm{CH}$, Chinese Hybrid; G, glabrous mutant. Values in column with the same letter are not significantly different $(P \leq 0.05$, DMRT) and should be considered together for IP and MP

plants. MP plants produced fewer than 3 female flowers per plant (Table 3) regardless of media and flowers were localized mainly on the upper part of the plant (Figs. 3, 1c). The first female flower produced by whole plants cultured on the MS and MSK medium were generally localized above the 4th node, second and third between 7th and 9th node, while fourth and fifth on the upper nodes (Fig. 1d). On both media the flowers were localized evenly on the plants, similar to the control.

We analyzed the morphology of male flowers with special attention to the presence or absence of anthers and their appearance (Table 5). In general male flowers obtained from tissue cultures were smaller than controls. Flowers on IPs had longer petals $(1.6 \pm 0.1 \mathrm{~cm})$ and were larger $(2.0 \pm 0.1 \mathrm{~cm})$ after opening than MP plants. However flowers produced by the MP plants had on average more petals $(5.2 \pm 0.1$ per plant). Some male flowers possessed no anthers or one or two degenerated anthers. IPs had the normal numbers of petals and anthers in each flower and we found no differences in their morphology as compared to control plants.

We observed tendril formation with flower-bud development for IPs grown on MS media that were PGR-free
Table 4 Average effect of the induction media on plant height and number of nodes ( \pm standard error) from intact and micropropagated cucumber plants

\begin{tabular}{|c|c|c|c|}
\hline \multirow[t]{2}{*}{ Medium } & \multicolumn{3}{|l|}{ Accession } \\
\hline & B & $\mathrm{CH}$ & $\mathrm{G}$ \\
\hline \multicolumn{4}{|c|}{ Plant height $(\mathrm{cm})$} \\
\hline \multicolumn{4}{|c|}{ Intact plants } \\
\hline MS & $26.7 \pm 2.3 \mathrm{a}$ & $24.9 \pm 1.1 \mathrm{a}$ & $20.9 \pm 2.6 a b$ \\
\hline MSB & $13.7 \pm 2.4 a b c$ & $14.8 \pm 2.9 \mathrm{abc}$ & $7.6 \pm 1.0 \mathrm{ab}$ \\
\hline MSK & $18.9 \pm 1.1 \mathrm{ab}$ & $18.2 \pm 1.8 \mathrm{ab}$ & $21.4 \pm 1.8 \mathrm{a}$ \\
\hline MSP & $4.1 \pm 0.7 b c$ & $11.8 \pm 2.5 \mathrm{abc}$ & $10.4 \pm 2.1 \mathrm{ab}$ \\
\hline \multicolumn{4}{|c|}{ Micro-propagated plants } \\
\hline MS & $16.3 \pm 0.5 \mathrm{abc}$ & $10.4 \pm 1.6 a b c$ & $12.8 \pm 1.2 \mathrm{ab}$ \\
\hline MSB & $6.2 \pm 1.0 \mathrm{bc}$ & $6.4 \pm 0.8 b c$ & $9.5 \pm 2.8 b$ \\
\hline MSP & $3.6 \pm 0.8 \mathrm{c}$ & $1.3 \pm 0.1 \mathrm{c}$ & $2.2 \pm 0.3 b$ \\
\hline \multicolumn{4}{|c|}{ No. of nodes per plant } \\
\hline \multicolumn{4}{|c|}{ Intact plants } \\
\hline MS & $19.0 \pm 0.7 \mathrm{a}$ & $15.0 \pm 0.4 \mathrm{a}$ & $11.0 \pm 1.4 \mathrm{a}$ \\
\hline MSB & $10.5 \pm 2.2 b$ & $10.8 \pm 2.5 \mathrm{ab}$ & $6.5 \pm 0.5 \mathrm{ab}$ \\
\hline MSK & $9.9 \pm 0.8 b$ & $8.6 \pm 0.9 b$ & $10.1 \pm 1.1 \mathrm{a}$ \\
\hline MSP & $2.3 \pm 0.4 \mathrm{~d}$ & $8.8 \pm 1.3 b$ & $7.1 \pm 1.2 \mathrm{ab}$ \\
\hline \multicolumn{4}{|c|}{ Micro-propagated plants } \\
\hline MS & $8.0 \pm 1.2 \mathrm{bc}$ & $7.9 \pm 1.7 \mathrm{a}$ & $8.6 \pm 0.7 \mathrm{ab}$ \\
\hline MSB & $5.6 \pm 1.5 \mathrm{bcd}$ & $5.8 \pm 0.8 b c$ & $7.4 \pm 1.7 \mathrm{ab}$ \\
\hline MSP & $4.3 \pm 0.3 \mathrm{~cd}$ & $1.3 \pm 0.1 \mathrm{c}$ & $3.8 \pm 0.5 b$ \\
\hline
\end{tabular}

B, inbred B; CH, Chinese Hybrid; G, glabrous mutant. Values in column with the same letter are not significantly different $(P \leq 0.05$, DMRT) and should be considered together for IP and MP

and supplemented with Kin. MP plants with tendrils were rare and observed only on PGR-free MS and only on plants with flower buds.

Pollen viability and germination in vitro

Pollen produced by in vitro developed flowers was less viable than control plants (Table 6, Fig. 4a-c). Relatively good viability $(62.1 \pm 5.7 \%)$ of pollen was observed from male flowers produced on IPs. There were significant differences in pollen viability depending on media. The highest pollen viability ( 73\%) was recorded on PGR-free MS and MSK media. Media supplemented with BA (MSB and MSP) decreased pollen viability in both experiments. Pollen germination from in vitro developed flowers and control plants was lower than the percentage of stained pollen (Fig. 4d-e). Approximately $70 \%$ of pollen from control plants germinated after $24 \mathrm{~h}$ on GM medium. There was no difference in percent germination among IP and MP plants. However we observed an effect of induction media on germination of pollen from in vitro flowers; the highest $(69.5 \pm 4.1 \%)$ pollen germination was observed from flowers developed on MS with Kin. 
Fig. 3 Average position of the first five female flowers on the main stem of intact (IP) and micropropagated (MP) cucumber plants and in greenhouse grown plants (Control) MS, MSB, MSK, $\mathrm{MSP}=$ induction media

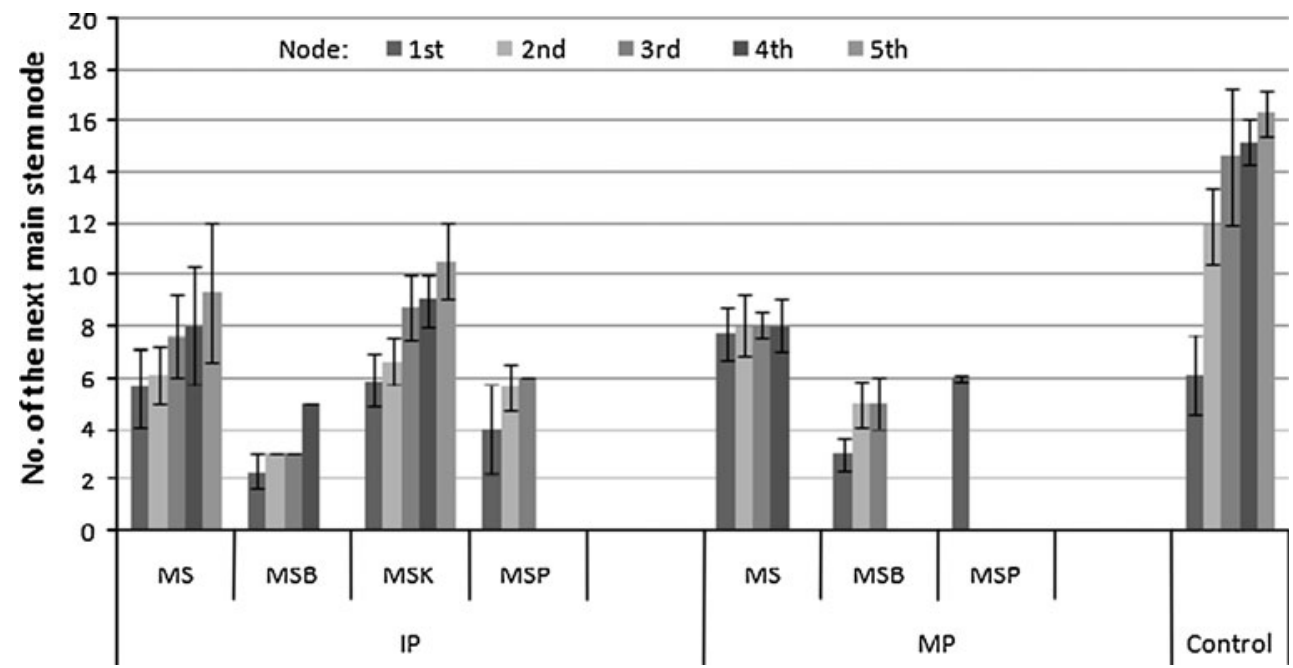

from $12.1 \pm 0.9$ to $37.9 \pm 2.1 \%$. Media had an effect on the frequencies of abnormalities; the highest percent of normal tetrads was observed for plants grown on PGR-free MS ( $88 \pm 2.3 \%$ for IPs and $61 \pm 2.6 \%$ for MP plants). On media with Kin we observed $79.2 \pm 5.0 \%$ normal tetrads (Fig. 6a). On media with BA (MSB and MSP medium), over $60 \%$ of cells sampled from IPs had normal meiosis, while in MP plants the percentage was lower $(47.8 \pm 5.0$ and $37.3 \pm 3.4 \%$, respectively).

The frequencies of monads (Fig. 6b), dyads (Fig. 6c), or triads (Fig. 6d) were relatively low $(0.3 \pm 0.1 \%$ on MS to $4.8 \pm 1.2 \%$ on MSB). Degeneration of tetrads (Fig. 6e), ranging from $5.4 \pm 1.0 \%$ on MS to $22.9 \pm 1.9 \%$ on MSP, was also a common abnormality observed in this study. Relatively high frequencies of polyads (Fig. 6f, g), ranging from $7.2 \pm 1.7$ to $23.7 \pm 1.5 \%$ were observed on MSP medium, lowest $(5.1 \pm 1.6-8.3 \pm 1.8 \%)$ in the pollen mother cell (PMC) collected from plants cultured on MS PGR-free medium. In this study, we observed that micronuclei remained in tetrads or were eliminated as microcytes (Fig. 6h). The mean percent micronuclei in PMC of IPs was lower $(0.1 \pm 0.1 \%$ on MS to $11.9 \pm 2.6$ on MSP $)$ than from MP plants $(5.3 \pm 1.4 \%$ on MS to $15.8 \pm 2.9 \%$ on MSP).

$I P$ Intact plants, $M P$ Micropropagated plants. Values in rows with the same letter are not significantly different $(P \leq 0.05$, DMRT)

Table 6 Pollen viability and germination ( \pm standard error) of in vitro developed male flowers and greenhouse grown plants (Control)

$I P$ intact plants, $M P$ micropropagated plants. Values in row with the same letter are not significantly different $(P \leq 0.05$, DMRT $)$

\begin{tabular}{llllll}
\hline Treatment & \multicolumn{2}{l}{ Medium } & \multicolumn{2}{l}{ Mean } \\
\cline { 2 - 5 } & MS & MSB & MSK & MSP \\
\hline Pollen viability $(\%)$ & & & \\
IP & $72.6 \pm 5.2 \mathrm{a}$ & $56.3 \pm 5.7 \mathrm{abc}$ & $72.9 \pm 4.2 \mathrm{a}$ & $46.6 \pm 7.8 \mathrm{bc}$ & $62.1 \pm 5.7 \mathrm{~b}$ \\
MP & $61.8 \pm 3.1 \mathrm{ab}$ & $48.6 \pm 4.0 \mathrm{bc}$ & - & $39.7 \pm 2.6 \mathrm{c}$ & $50.1 \pm 3.2 \mathrm{c}$ \\
Control & & & & $90.6 \pm 1.5 \mathrm{a}$ \\
Pollen germination $(\%)$ & & & & \\
IP & $54.3 \pm 6.0 \mathrm{ab}$ & $43.5 \pm 5.0 \mathrm{bc}$ & $69.5 \pm 4.1 \mathrm{a}$ & $41.9 \pm 4.9 \mathrm{bc}$ & $52.3 \pm 5.0 \mathrm{~b}$ \\
MP & $46.8 \pm 3.1 \mathrm{bc}$ & $39.5 \pm 4.0 \mathrm{bc}$ & - & $31.5 \pm 2.9 \mathrm{c}$ & $39.3 \pm 3.3 \mathrm{~b}$ \\
Control & & & & & $69.2 \pm 4.8 \mathrm{a}$ \\
\hline
\end{tabular}




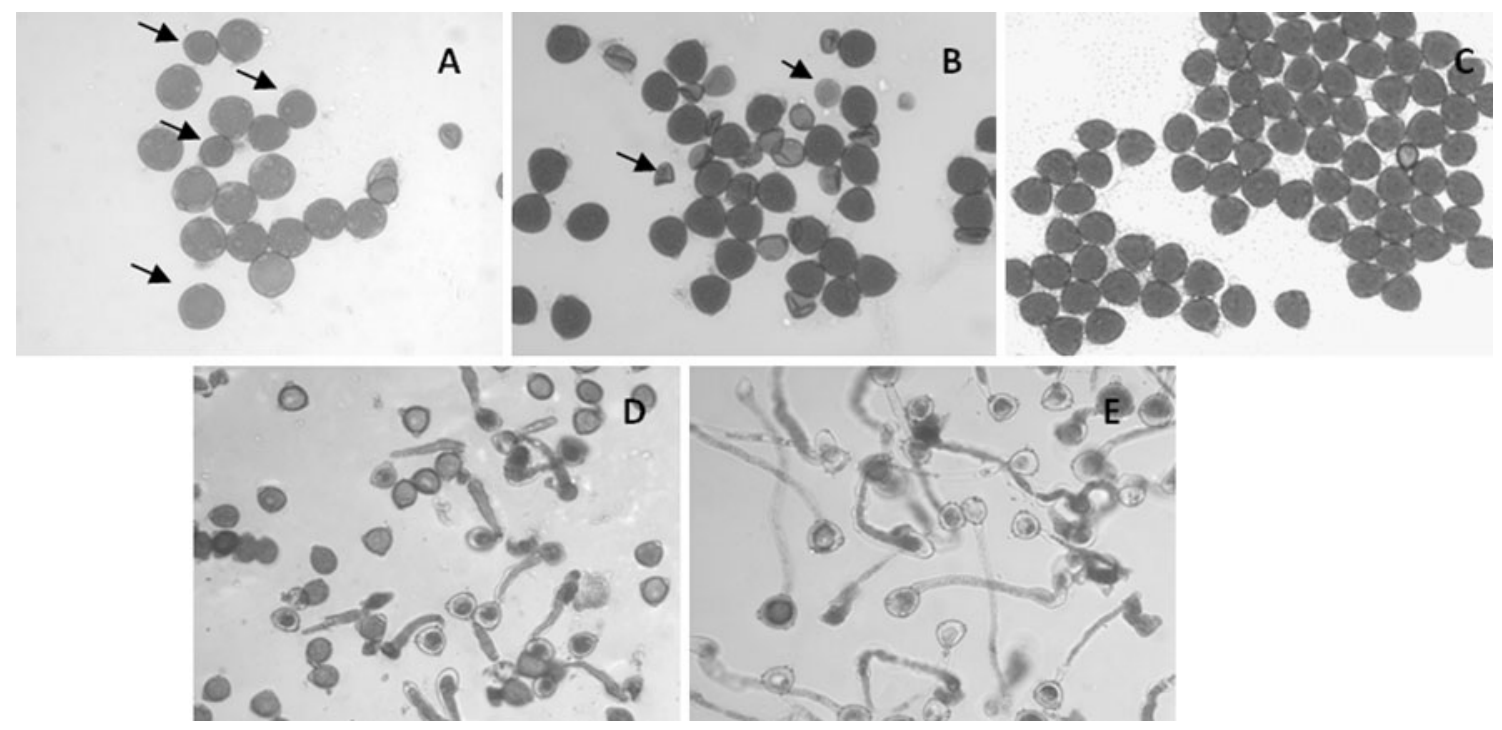

Fig. 4 Pollen viability and germination in cucumber. Viable pollen grains of different size (a) and dead pollen (b) indicated by arrows, from in vitro flowered plants; Control (c). Germination of pollen from in vitro flowering plants (d); Control (f). Magnification $\times 200$

Fig. 5 Mean percent of normal tetrad formation and abnormalities in the meiosis in PMC of intact (IP) and micropropagated (MP) plants flowered in vitro and in greenhouse grown plants (Control) MS, MSB, MSK, $\mathrm{MSP}=$ induction media

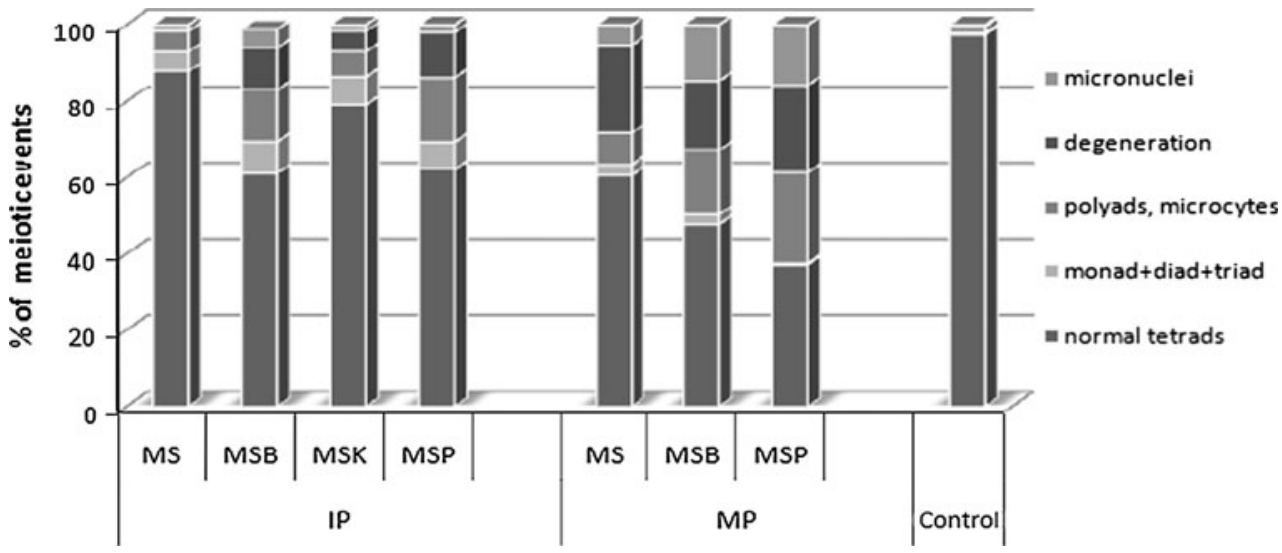

\section{Discussion}

Explant source is a factor determining success of in vitro flowering (Taji et al. 2002; Scorza 1982), and in our study intact plants and stem fragments were used. To our knowledge, neither of these sources has been tested in cucumber for the ability to produce flowers tissue culture. We compared the efficiency of flower production and quality of pollen using different explant sources and PGRs.

Msikita et al. (1990) reported production of shoots from cucumber cotyledons on a medium supplemented with $8.9 \mu \mathrm{M} \mathrm{BA}$ and $1.6 \mu \mathrm{M} \mathrm{NAA}$, but as in our study it was accompanied by callus formation. They reported flowering of some shoots developing from cotyledonary explants after 7 weeks, but no flowering occurred on the plants regenerated from embryonic axis explants. Rajasekaran et al. (1983) reported flowering on hypocotyl-derived shoots after 20 weeks of culture on MS medium supplemented with BA and 2,4-D. Tisserat and Galletta (1993) reported flowering of cucumber plants derived from shoot tips after 6-12 weeks of culture. In our study we were able to induce flowering in both types of explants and in all media combinations, except MSC. Flowering in our study started in the 4th week of culture in IPs and in about the 8th week in MP plants. These reports and our results demonstrate the importance of explant source. Base on our observations the processes of shoot development from explants, differentiation of shoot to flower meristems, and finally flowering was about two fold longer in MP plants as compared to IP plants. The determination to develop flowers may be strong in certain tissues or organs and this determination may carry through from donors to explants (Taji et al. 2002), and may explain the observed differences in the time of flowering between plants regenerated from stem fragments as compared to intact plants.

IP plants did not flower after transfer to MS medium supplemented with $8.9 \mu \mathrm{M}$ BA and $1.1 \mu \mathrm{M}$ NAA. Roots and the basal part of the stem, in contact with the medium, 


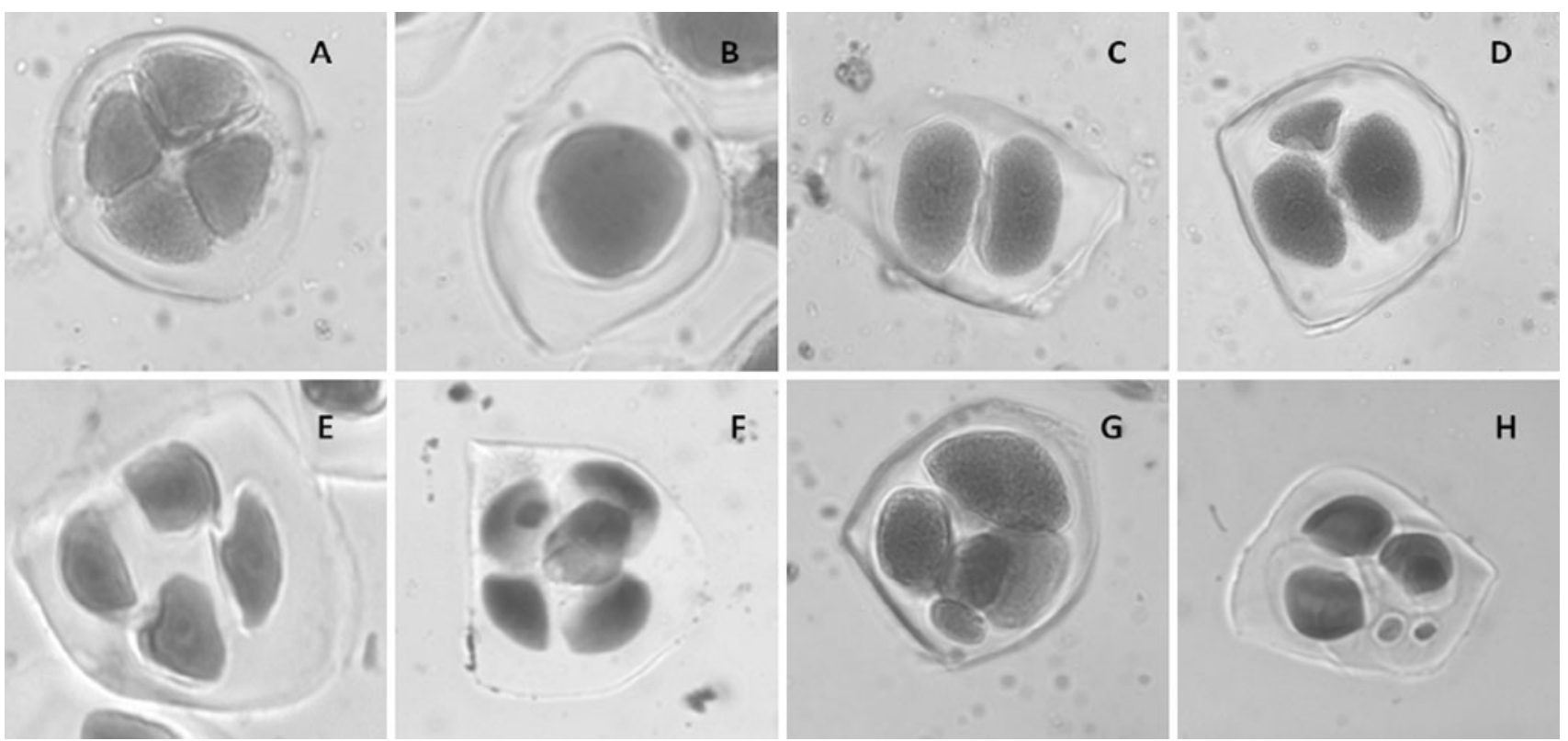

Fig. 6 Meiotic products from anthers of cucumber flowers developed in vitro. Normal tetrad (a), monad (b), dyad (c), triad (d), degenerating tetrad $(\mathbf{e})$, polyads $(\mathbf{f}$ and $\mathbf{g})$, tetrad with micronuclei eliminated as microcytes $(\mathbf{h})$. Magnification $\times 400$

were covered quickly by greenish-white callus. This callus layer may have prevented uptake of the nutrients from the medium, killing the plant. Our results contrast with those reported for tobacco. Peeters et al. (1991) cultured tobacco cortex strips on MS medium with different levels of auxins and cytokinin; optimal flower bud formation occurred on a medium with $1.0 \mu \mathrm{M}$ auxin (indole-3-acetic acid (IAA), IBA, or NAA) and $1.0 \mu \mathrm{M}$ cytokinin (BA). At low concentrations of BA (i.e. $0.1 \mu \mathrm{M}$ ), explants did not form flower buds. An increase of either auxin or cytokinin concentration increased bud numbers. At higher cytokinin and lower auxin concentrations, flower bud formation was delayed; however in our study, such combinations failed to induce flower bud formation in both experiments. Msikita et al. (1990) reported production of flowers from cotyledonary-derived shoots of cucumber on medium supplemented with $17.7 \mu \mathrm{M}$ BA and 1.6 $\mu \mathrm{M}$ NAA; however only few, poorly developed female flowers were observed on medium supplemented with $8.9 \mu \mathrm{M}$ BA and $1.6 \mu \mathrm{M}$ NAA. Wang et al. (2001) reported that MS medium with addition of $8 \mu \mathrm{M}$ Kin promoted the female flowers formation in bitter melon. Moreover BA promoted male flower formation at concentration $1-2 \mu \mathrm{M}$, but completely inhibited any flower formation at 4-8 $\mu \mathrm{M}$. In our experiment we observed male flowers on medium with $8.9 \mu \mathrm{M}$ of $\mathrm{BA}$; however production of female flowers decreased. BA is the most effective cytokinin for the induction of flowering in bamboo (John and Nadgauda 1999), orchids (Hee et al. 2007), chamomile (Kintzios and Michaelakis 1999) and rose (Kanchanapoom et al. 2009). Kin was more favorable than other cytokinins in flower formation in buckwheat
(Kachonpadungkitti et al. 2001). In contrast, Wittwer and Aung (1969) showed that Kin inhibited flowering in whole plants of tomato. These results indicate that induction of flowering is a complex process and there is no universal combination of plant growth hormones that induce flowering in tissue culture. In general auxins are considered as inhibitors of flowering, while cytokinins are more successful for in vitro induction of flower bud formation (Taji et al. 2002; Scorza 1982).

Although the influence of different forms and concentration of sugars and $\mathrm{Fe}$ ions was not investigated in our study, we made some very interesting observations. Sugars are necessary carbon sources in culture media for induction and development of flowers (Kanchanapoom et al. 2010a, b; Ohto et al. 2001; Scorza 1982). Wang et al. (2001) reported that $150 \mathrm{mM}$ sucrose promoted male flower production in bitter melon, but no flowering occurred on media supplemented with $90 \mathrm{mM}$ or $210 \mathrm{mM}$ of sucrose. In our study we used $90 \mathrm{mM}$ sucrose in all of the used media and we observed flowering in vitro. The same group of authors observed rapid chlorosis of bitter melon regenerants when cultured on standard PGR-free MS medium. To prevent chlorosis they increased the content of $\mathrm{Fe}^{2+}$ to $0.15 \mathrm{mM}$ and concluded that increased content of $\mathrm{Fe}$ ions together with addition of $8 \mu \mathrm{M}$ Kin increases chlorophyll content and promoted in vitro flowering. In our study we observed a different reaction, in spite that these two cucurbits are related in the same family (Stepansky et al. 1999). We used MS medium with $0.1 \mathrm{mM} \mathrm{Fe}^{2+}$ added as the disodium salt of ethylene diamine tetra acetic acid (EDTA). Among plants cultured on the media with BA, shoot tip chlorosis 
was observed, but flower buds were produced. Moreover, on PGR-free MS, or when supplemented with $6 \mu \mathrm{M}$ Kin, we observed the highest rate of normal flowering with no chlorosis. Our findings suggest that it is not necessary to increase $\mathrm{Fe}$ content to induce flowering in cucumber.

Our results demonstrated that, if flower induction is preceded by a phase of multiplication and regeneration on media with hormones, it may change the morphology of regenerated plants. Whole plants seem to be less susceptible to in vitro culture, and no differences in flower morphology were observed as compared to greenhouse-grown controls. Increasing incidence of morphological changes following regeneration after various cycles of in vitro culture of different explants has been reported in cucumber (Burza et al. 1996; Pląder et al. 1998), as well as in other plants (Breiman et al. 1989; Hee et al. 2007; Nikolić et al. 2006; Winarto et al. 2011).

Ameha et al. (1998) reported development of tendrils in regenerants from in vitro cultured whole seeds and seed fragments of 'Early Spring Burpless' cucumber. Tendrils developed simultaneously with flower bud formation mainly on medium with mixture of gibberelic acid A4 and A7 $\left(\mathrm{GA}_{4+7}\right)$. Our results confirm that the formation of tendrils in cucumber is closely associated with flower bud formation, but their development can also occur on PGR-free medium.

To our knowledge, there are no reports about pollen viability and germination from in vitro induced flowers of cucumber and pollen fertility has not been assessed (Rajasekaran et al. 1983; Tisserat and Galletta 1993). Although microscopic examinations found no differences in the morphology of pollen from in vitro and in vivo developed flowers (Msikita et al. 1990), no details on pollen viability were reported.

In cucumber normal meiosis in PMCs produces four microspores grouped together in a tetrad (Heimlich 1927). Absence of cytokinesis can result in monads, dyads, or triads, other disturbances of meiosis may lead to micronuclei and degeneration of tetrads (Diao et al. 2010; Passmore 1930). Irregularities during early stages of meiosis may cause chromosome fragmentation or irregular segregation. This fragmentation results in the formation of polyads with the different number and sizes of microspores produced (Fig. 4a) and microcytes, fractionating the genome and causing pollen sterility (Fuzinatto et al. 2007). Polyads observed in our study suggests that irregularities were present since first meiotic division. Micronuclei may originate from chromosome fragments lacking a centromere or whole chromosomes which were unable to migrate during anaphase (Fenech 2000; Dhooghe et al. 2011). The observed meiotic changes are possibly due to medium composition, plant hormones and genetic background of the explants (Bayliss 1980; Golczyk 1994; Nadgauda et al. 1997; Sarkar et al. 2010).

\section{Conclusions}

We studied the viability of pollen produced on cucumber plants flowered in vitro, with the long-term goal to induce microspore embryogenesis in cucumber using in vitro flowering plants. We evaluated flowering and pollen viability for in vitro grown plants using three cucumber accessions, two types of explants, and various MS medium combinations. Significant differences in flower morphology were observed for explant sources, in agreement with previous research showing that flowering in vitro is affected by different PGRs (Taji et al. 2002; Scorza 1982). Our study demonstrated that PGR-free medium can stimulate flowering on intact plants and micropropagated shoots of cucumber. Addition of BA induced flowering, but the morphology of the plantlets and flowers was altered. Analysis of tetrads revealed that meiotic abnormalities were the main causes of lowered pollen viability. The lowest rate of meiotic irregularities was observed in plants grown on PGR-free MS; however the addition of Kin did not significantly increase meiotic abnormalities. The highest frequency of normal plants with no chlorosis, earliest flowering, and the highest percent of germinable pollen was observed using MS with $6 \mu \mathrm{M}$ Kin.

Acknowledgments Names are necessary to report factually on available data; however, the U.S. Department of Agriculture (USDA) neither guarantees nor warrants the standard of the product, and the use of the name by USDA implies no approval of the product to the exclusion of others that may also be suitable. This work was supported by the USDA Agricultural Research Service.

Open Access This article is distributed under the terms of the Creative Commons Attribution Noncommercial License which permits any noncommercial use, distribution, and reproduction in any medium, provided the original author(s) and source are credited.

\section{References}

Alexander MP (1969) Differential staining of aborted and nonaborted pollen. Stain Technol 44:117-122

Al-Khayri JM, Huang FH, Morelock TE, Busharar TA (1992) In vitro seed production from sex-modified male spinach plants regenerated from callus cultures. Scientia Hort 52:277-282

Ameha M, Skirvin RM, Mitiku G, Bullock D, Hoffman P (1998) In vitro tendril and flower development in cucumber (Cucumis sativus) may be regulated by gibberellins. J Hortic Sci Biotechnol 73:159-163

Bayliss MW (1980) Chromosomal variation in plant tissues in culture. Int Rev Cytol 11a:113-144

Bhat MA, Mujib A, Junaid A (2010) In vitro regeneration of Solanum nigrum with enchanced solasodine production. Biol Plant $54: 757-760$

Bodhipadma K, Noichinda S, Padyencheun W, Khunthacharoen T, Chikhunthod U, Leung DWM (2011) Influence of preculture treatment and types of explant on shoot growth and in vitro flowering of feathered amaranth (Celosia argentea var plumose). Plant Cell Tiss Organ Cult 105:465-469 
Breiman A, Felsenburg T, Galun E (1989) Is Nor region variability in wheat invariably caused by tissue culture? Theor Appl Genet 77:809-814

Burza W, Malepszy S (1995) Direct regeneration from leaf explants of cucumber (Cucumis sativus L.) is free of stable genetic variation. Plant Breed 114:341-345

Burza W, Malepszy S, Rostek E (1996) The effect of simple and recurrent in vitro regeneration on a cucumber inbred line under field cultivation. Hort Sci 28:11-13

Dhooghe E, Van Laere K, Eeckhaut T, Leus L, Huylenbroeck Van (2011) Mitotic chromosome doubling of plant tissues in vitro. Plant Cell Tissue Organ Cult 104:359-737

Diao WP, Bao SY, Jiang B, Cui L, Qian CT, Chen JF (2010) Cytological studies on meiosis and male gametophyte development in autotetraploid cucumber. Biol Plant 54:373-376

Fenech M (2000) The in vitro micronucleus technique. Mutat Res 455:81-95

Franklin G, Pius PK, Ignacimuthu S (2000) Factors affecting in vitro flowering and fruiting of green pea (Pisum sativum L.). Euphytica 115:65-73

Fuzinatto VA, Pagliarini MS, Valle CB (2007) Microsporogenesis in sexual Bracharia hybrids (Poaceae). Genet Mol Res 6:1107-1117

Golczyk H (1994) Cytological changes in tissue culture of Allium sibiricum L. Acta Biol Crac 36:31-37

Hee KH, Loh CS, Yeoh HH (2007) Early in vitro flowering and seed production in culture in Dendrobium Chao Praya Smile (Orchidaceae). Plant Cell Rep 26:2055-2062

Heimlich LF (1927) Microsporogenesis in the cucumber. Botany 13:113-115

Hu WH, Chang C, Peng CI, Liaw SI (2010) In vitro flowering and fruiting of Begonia parvula H. Lev. \& Vaniot. Eur J Hort Sci 75:172-176

Inggamer H, de Ponti B (1980) The identity of genes for glabrousness in Cucumis sativus L. Cucurbit Genet Coop Rpt 3:14

Jana S, Shekhawat GS (2011) Plant growth regulators, adenine sulfate and carbohydrates regulate organogenesis and in vitro flowering of Anethum groveolens. Acta Physiol Plant 33:305-311

John CK, Nadgauda RS (1999) In vitro-induced flowering of bamboos. In Vitro Cell Dev Biol Plant 35:309-315

Jumin HB, Ahmad M (1999) High-frequency in vitro flowering of Murraya paniculata (L.) Jack. Plant Cell Rep 18:764-768

Kachonpadungkitti Y, Romchatngoen S, Hasegawa K, Hisajima S (2001) Efficient flower induction from cultured buckwheat (Fagopyrum esculentum L.) node segments in vitro. Plant Growth Reg 35:37-45

Kanchanapoom K, Posayapisit N, Kanchanapoom K (2009) In Vitro flowering from cultured nodal explants of rose (Rosa hybrida L.). Not Bot Hort Agrobot Cluj 37:261-263

Kanchanapoom K, Jingjit S, Kanchanapoom K (2010a) In Vitro flowering of shoots regenerated from cultured nodal explants of Gypsophila paniculata L. Not Bot Hort Agrobot Cluj 39:84-87

Kanchanapoom K, Sakpeth P, Kanchanapoom K (2010b) In Vitro flowering of shoots regenerated from cultured nodal explants of Rosa hybrida cv. 'Heirloom'. Sci Asia 36:161-164

Kintzios S, Michaelakis A (1999) Induction of somatic embryogenesis and in vitro flowering from inflorescens of chamomile (Chamomilla recutita L.). Plant Cell Rep 18:684-690

Kumar VA, Kumar A, Kumar J (1995) In vitro flowering and pod formation in cauliflower (Brassica oleracea var botrytis). Curr Sci 69:543-545

Lin Ch-S, Lin Ch-Ch, Chang W-Ch (2003) In vitro flowering of Bambusa edulis and subsequent plantlet survival. Plant Cell Tissue Organ Cult 72:71-78

Masmoudi-Allouche F, Meziou B, Kriaa V, Gargouri-Bouzid R, Drira $\mathrm{N}$ (2010) In vitro flowering induction in date palm (Phoenix dactylifera L.). J Plant Growth Regul 29:35-43
Msikita W, Skirvin RM, Juvik JA, Splittstoesser WE, Ali N (1990) Regeneration and flowering in vitro of 'Bulpress Hybrid' cucumber cultures from excised seed. Hort Sci 25:474-477

Murashige T, Skoog F (1962) A revised medium for rapid growth bioassays with tobacco tissue culture. Physiol Plant 15:473-497

Nadgauda RS, John CK, Parasharami VA, Joshi MS, Mascarenhas AF (1997) A comparison of in vitro with in vivo flowering in bamboo: Bambusa arundinacea. Plant Cell Tissue Organ Cult 48:181-188

Nikolić R, Mitić N, Miletić R, Nešković M (2006) Effects of cytokinins on in vitro seed germination and early seedling morphogenesis in Lotus corniculatus L. J Plant Growth Regul 25:187-194

Ohto M, Onai K, Furukawa Y, Aoki E, Araki T, Nakamura K (2001) Effects of sugar on vegetative development and floral transition in Arabidopsis. Plant Physiol 127:252-261

Passmore SF (1930) Microsporogenesis in the Cucurbitaceae. Bot Gaz 90:213-223

Peeters AJM, Gerards W, Barendse GWM, Wullems GJ (1991) In vitro flower bud formation in tobacco: interaction of hormones. Plant Physiol 97:402-408

Pląder W, Malepszy S, Burza W, Rusinowski Z (1998) The relationship between the regeneration system and genetic variability in the cucumber (Cucumis sativus L.). Euphytica 103:9-15

Rajasekaran K, Mullins MG, Nair Y (1983) Flower formation in vitro by hypocotyls explants of cucumber (Cucumis sativus L.). Ann Bot 52:417-420

Ramanayake SMSD, Wanniarachchi WAVR, Tennakoon TMA (2001) Axillary shoot proliferation and in vitro flowering in an adult giant bamboo, Dendrocalamus gigantus Wall. Ex Munro. In Vitro Cell Dev Biol Plant 37:667-671

Sarkar D, Sharma S, Chandel P, Pandey SK (2010) Evidence for gametoclonal variation in potato (Solanum tuberosum L.). Plant Growth Regul 61:109-117

Scorza R (1982) In vitro flowering. Hort Rev 4:106-127

Sheeja TE, Mandal AB (2003) In vitro flowering and fruiting in tomato (Lycopersicon esculentum Mill.). Asia Pac J Mol Biol Biotechnol 11:37-42

Song H, Lou Q, Lou X, Wolukau J, Diao W, Qian C, Chen J (2007) Regeneration of doubled haploid plants by androgenesis of cucumber (Cucumis sativus L.). Plant Cell Tissue Organ Cult 90:245-254

Stepansky A, Kovalski I, Perl-Treves R (1999) Intraspecific classification of melons (Cucumis melo L.) in view of their phenotypic and molecular variation. Plant Syst Evol 217:313-333

Taha RM, Hasbullah NA, Awal A (2010) In vitro flowering of selected ornamental plants. Acta Hortic 881:141-146

Taji A, Kumar P, Lakshmanam P (eds) (2002) In vitro flowering: its relevance to plant breeding. In: In vitro plant breeding. Haworth Press Inc., New York, pp 127-140

Tisserat B, Galletta PD (1993) Production of cucumber fruits from the culture of 'Marketmore-76' plantlets. Plant Cell Rep 13:37-40

Tisserat B, Galletta PD (1995) In vitro flowering and fruiting of Capsicum fruitescens $\mathrm{L}$. HortScience 30:130-132

Vižintin L, Bohanec B (2004) In vitro manipulation of cucumber (Cucumis sativus L.) pollen and microspores: isolation procedures, viability tests, germination, maturation. Acta Biol Crac 46:177-183

Wang S, Tang L, Chen F (2001) In vitro flowering of bitter melon. Plant Cell Rep 20:393-397

Winarto B, Rachmawati F, Pramanik D, Teixeira da Silva JA (2011) Morphological and cytological diversity of regenerants derived from half-anther cultures of anthurium. Plant Cell Tissue Organ Cult 105:363-374

Wittwer SH, Aung LH (1969) Lycopersicon esculentum Mill. [In:] LT Evans (ed) The induction of flowering: Some Case Histories. Cornell University Press, Ithaca, pp 409-423 